\title{
İnsan ve rat karaciğer primer hücre kültürlerinde farklı N-nitroso bileşiklerinin DNA üzerindeki etkileri
}

\author{
Taner PAMUKÇU', Alexandre SCOTT ${ }^{2}$ \\ ' Kırıkkale Üniversitesi. Veteriner Fakültesi. Biyokimya Anabilim Dali, Kırıkkale: ’ Straytclyde C̈niversitesi, Biyoloji Böltümui. \\ Glasgow
}

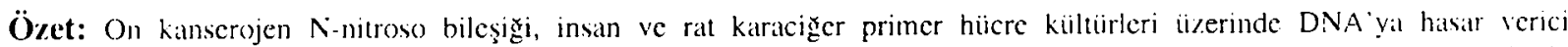
aktiviteleri açısından denendi; alkaline clüsyon teknið̆i kullanılarak DNA bölünmesi ve nicel otoradyografi kullatmılarak da programlanıamıs DNA sentezleri ölçüldui. Subıoksik konsantrasyonların aralığında pozitif doclat ilgili cevaplar her iki türïn hiicrelcrinden $10-32 \mathrm{mM}$ 'lik $\mathrm{N}$-nitrosodicthylamine, 1,8-10 mM'lik $\mathrm{N}$-nitrosodi-n-propylamine, 1-3.2 $\mathrm{mM}$ lik $\mathrm{N}$-nitrosomorpholine.

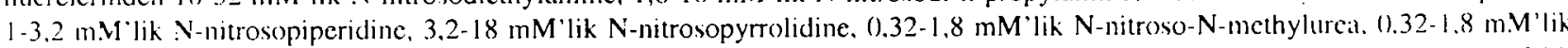

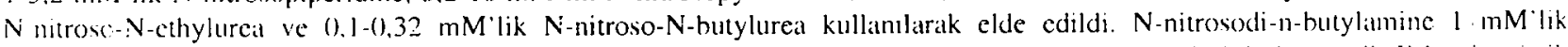
doymuş cözeltisi sabitti. Insian karaciğer hücrelerinin tepkileri nitelik açısından rat karacił̆ger hüicreleriyle benzerdi. Fakall ișlitistik açidin. N-nitrosodimethylamine, N-nitrosomorpholinc. $N$-nitrosopiperidine, $N$-nitrosopyrolidine ve $N$-nitrosio-N-butylureit kullamılarak gözlemlenen programlanmammş DNA sentezlerinde ve DNA hasar miktarlarında iki tiir arasında öncmli farklılıklar

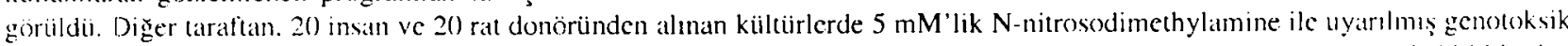
etkilerdeki miktarsal farklılıklar bu nitrosamine ve diğer $\mathrm{N}$-nitroso bileşikleriyle ortaya çıarılan ortalama tiirler arası fiarklılıklardan daha büyüktï. Rat hepatositlerindeki DNA onarım duyarlılığını işaret eden bu sonuçlar, insan hepatositlerindeki $N$-nitrosos bileşiklerinin genotoksik potansiyelini tahmin etmek için geçerli bir model olduğunu gösterdi.
\end{abstract}

Anahtar kelimeler: DNA hasarn, insan, karaciğer primer hücre kuiltürï, $N$-nitroso bileşikleri, rat

\section{The effects of different $\mathrm{N}$-nitroso compounds in primary cultures of human and rat hepatocytes on the DNA}

Summary: Ten carcinogenic $N$-nitroso compounds were examined for DNA-damaging activity in primary cultures of humaln and rat hepatocytes. DNA fragmentation was measured by the alkaline elution technique, and unscheduled DNA synthesis was by guantitative autoradiography. Positive dose-related responses in the range of subtoxic concentrations indicated were obtained in cells of hoth species with $N$-nitrosodiethylamine ( 10$)-32 \mathrm{mM})$. N-nitrosodi-n-propylamine $(1.8-10 \mathrm{mM})$. $\mathrm{N}$-nitrosomorpholine $(1-3.2 \mathrm{mM})$. $\mathrm{N}$ untrosopiperidine (1-3.2 mM), $\mathrm{N}$-nitrosopyrrolidine $(3.2-18 \mathrm{mM}), \mathrm{N}$-nitroso-N-methylurea (0.32-1.8 mM). $\mathrm{N}$-nitroso- $\mathrm{N}$-cthylurea (0.32-1.8 mM) and $N$-nitroso- $N$ butylurea (0.1-0.32 mM). N-nitrosodi-n-butylamine was practically inactive at the maximal soluble concentration $(1 \mathrm{~m}: \mathrm{M})$. The results obtained from human hepatocytes were qualitatively similar to those of rat hepatocyles. but statistically, important differences between the two species in the amounts of DNA damage and/or unscheduled DNA synthesis were observed with $N$-nitrosodimethylamine. $N$-nitrosomorpholine, $N$-nitrosopiperidine. $N$-nitrosopymolidine and $N$-nitroso- $N$ butylurea. On the other hand, quantitative differences in the genotoxic effects induced by $5 \mathrm{mM}$ - $\mathrm{N}$-nitrosodimethyliumine in cultures derived from 20 human donors and from 20) rat were greater than average compounds. These results indicate that the rat hepitocyte DNA repair assay is a vitid interspecies differences displayed by this nitrosamine and by other $\mathrm{N}$-nitroso model for predicting the genotoxic: potential of $\mathrm{N}$-nitroso compounds in human hepatocytes.

Key words : DNA damatec, hepatocyte. human, N-nitroso compounds. rat

\section{Giriş}

$\mathrm{N}$-nitroso bileşikleri (NOC)'nin birçok hayvan türünde tü mör oluşumuna neden olduğu ortaya çıkarılmıştır $(2.9,14.20)$. Kuvvetli kanserojen aktiviteleri nedeniyle, NOC:un geniş çevresel oluşumları, ön anminlerden ve a çiideki etkileri, belirli bölgelerdeki artan kanser olayları ile ilişkilendirilmesini ve insamın maruz kaldığ miktann Layin eciilmesini sağlamıştır $(14,19.29,32)$. Bartsch ve Montesano (1) in vivo olarak oluşan ya da mesleki ve fevesel nedenlerle ortanda olan NOC"yr maruz kalan insanların bu bileşiklerin kanserojen etkilerine karşı duyarlılıkların biyokimyasal, patolojik. dencysel ve epidemiyolojik incelemelerden elde edilen somuçlar ışığında incelemişlerdir. Metabolizmadaki nitrozaminler genellikle karaciğere karaciğer dışı dokulardan daha yïksck oranda ilgi gösterdiği için. insan karaciğerindeki kimyasal maddelerin biyolojik aktivitelerinin değerlendirilmesi için güvenilir bir modeli olarak gösterilen insan karaciğer dokularının primer kültürleri üzerinde dencyler yapılmıştır. $(6,8,13,24,34)$. DNA bölünnıesi. alkaline elïsyon tekniği (17) ve nükleon başına net ağırlık olarak mik- 
larsal otoradyografi (36) yoluyla programlanmamı̧ DNA sente\%i (UDS) kullanılarak değcrlendirilmiştir. Model olarak ratın kullanılmasının doğruluğunu kontrol etmek, risk miklarlarındaki değerler konusunda daha iyi bilgi sağlamak ve NOC'nin potansiyel kanserojen özclliklerini bulmak amacıyla, ratın karaciğger hücrelerinin primer kültiirlerindeki aynı uç noktalar ölçülerek bir karşılaşırma yapılmışur $(3,15,37)$.

Bu çalışımada, insandaki NOC'nin potansiycl genotoksik aktivitesi konusunda ek bilgi edinmek için insan hücrelerindeki DNA'nın onarım ve hasarı ile ilgili sentezleri ve kist oluşum kapasiteleri konusunda on kimyasal madde incelenmiştir.

\section{Materyal ve Metot}

\section{Karaciğer primer hücre kültürleri}

Çalışmanın materyalini operasyon sonrası atılacak olan taze insan karaciğer dokuları ve Sprague-Dawley erkek albino ratlarından alınan karaciğer dokuları oluşuurdu. Karaciğer donörlerinin sonuçlanı Tablo l'de sunuldu. Karacig̨er hiicreleri, daha önce Strcm ve ark. (33) tarafından tarif edildił̧ gibi kesik yüzeydeki büyük kan damarlarına sokulan sondalar sayesinde kollajen perfüzyonla sağlıklı dokudan ayrıldı. Çeşitli donörlerden elde edilen karaciğer hücreleri, $5 \times 10^{69}$ dan $10 \times 10^{99}$ a kadar sulandırıldı. Trypan blue exclusion'la ölçuildügü gibi perfüzyondan sonra kullanılabilir hücre oranlan Tablo l'de sunuldu.

Rat karaciğer hücrcleri, Williams (35) tarafından tarif edildiği gibi kollajen perfüzyon yoluyla, SpragueDawley erkek albino ratlarından (200'den 250 g'a kadar) clde edildi. Kullanılabilir hücre oranlan \% $\% 0^{\prime}$ den $\% 95^{\prime} \mathrm{c}$ kadar smiflandrrilds.

tzole insan ve rat karaciğer hücreleri, \%10 fötal dana serumu ve $50 \mathrm{mg} / \mathrm{ml} l i k$ gentamisin içinde muhafaza edildi. Bu süspansiyon eşit miktarlarda aşağıda tarif edildiği gibi plastik kapların içine yerleştirildi. DNA bölinnmesi üzerine yapılacak dency için $60 \mathrm{~mm}$ 'lik açık kapların içine $2 \times 10^{\prime}$ hücre ve UDS' nin belirlenmesi amacıyla yapılacak dency için ise kollajen ile kaplanmıs 3,5 mm'lik kaplar içine $1 \times 10^{\prime \prime}$ hücre yerleştirildi. \%95'i hava, $\% 5^{\circ} \mathrm{i} C \mathrm{CO}$ 'den oluşan bir atmosferde $37^{\circ} \mathrm{C}$ 'lik 1 sı altunda 3 saatlik ek bir süreden sonra, karaciğger hücreleri serumsuz. Williams hücre kültürü medyumu (WME) içinde test bileşiğ ile 20 siat sürcyle inkübasyona bırakıldı. NOC kullanımdan hemen önce direkt olarak ortamından ayrıldı ve $10 \mu \mathrm{Ci} / \mathrm{ml}$ [metill- ${ }^{-} \mathrm{H}$ ] timidin inkübasyon ortamına ilave edildi.

Bu işlemin bitiminde hücreler, trypan bluc cxclusion yoluyla sitotoksisite, DNA bölünmesi ve UDS için denendi.

\section{Kullanılan N-nitroso bileşikleri}

10-32 mM'lik N-nitrosodiethylamine (NDFA), 1.81) mM'lik N-nitrosodi-n-propylamine (NDPA), 1-3,2 mM'lik N-nitrosomorpholine (NMOR), 1-3,2 mM'lik $\mathrm{N}$ nitrosopiperidine (NPIP), 3,2-18 mM'lik N-nitrosopyrrolidine (NPYR), 0.32-1.8 mM'lik $\mathrm{N}$-nitroso- $\mathrm{N}$-methylureal (NMU), 0,32-1.8 m.M'lik N-nitroso-N-chylurea (NEU), 0,1-0,32 mM'lik N-nitroso-N-butylurea (NBU), $1 \mathrm{mM}$ 'lik doymuş çözeltisi sabit N-nitrosodi-n-butylamine (NI)BA), 5 mM'lik N-nitrosodinethylamine (NDMA).

\section{DNA bölünmesi ve alkalin elüsyon tekniği}

DNA bölünmesi, daha önce tarif edildiği gibi (4) al kalin elüsyon teknið̧i ile değerlendirildi. Bu teknikle. tek zincir kırıkları olan DNA'nun ve/veya alkaliyc dayanısı\% bölgelerin mevcudiyeti, kontrollerle karşlaştırıldı ğ gibi. hızlandırlmış DNA elüsyonu ile ortaya çıkanldı. Sonuçlar hem filtreden yıkanıp giderilmiş DNA'nın yiizde oranı olarak hem de kontroller $(\mathrm{Kt}-\mathrm{Kc}$ ) ïzerinden ellisyon oranı olarak ifade edildi. Denklem aşag̣ıdaki gibi oluşturulur.

$$
\mathrm{K}=\frac{(-\ln F R)}{\mathrm{V}}
$$

$\mathrm{K}\left(\mathrm{ml}^{-1}\right)$ : DNA clissyonunun başlangıç oram

FR: Filtre iizerinde kalan DNA

$\mathrm{V}$ : Elüsyon miktarı $(13 \mathrm{ml})$

"K" dirckt bir şekilde tek zincirkırılma sayısı ile orantulıdır.

\section{DNA onarım sentezleri ve otoradyografik deneme}

UDS, Williams'a göre (36) küiçük değişikliklerle otoradyografik olarak izah edilir (21). Hem insan hem de ratlarda yüzer adet hücre üzerinden değerlendirme yapıldı. Nükleus üzerindeki gümüş tanecikler eksi otoplazma içinde eşit boyuttaki bir saha üzerindeki tanecikler her bir nụkkleus başına net ağılılık olarak hesaplandı. NüikIcuslan gümüş tanecikleri ile çok yoğun bir şekilde ișaretli olan $S$ safhasındaki hücreler kolay bir şekilde fark edildi.

Bu çalışma, Straytclyde Üniversitesi Biyoloji Bölümü Laboratuvarlarında gerçekleştirildi.

\section{Bulgular}

Sitotoksisite konusundaki ön veriler, incelenen 10 adet NOC'nin, farklı konsantrasyonlarma 20) saat süre ile serumsuz WME uygulanan rat karaciğcr hücrelerinden arta kalan fraksiyonların ölçülmesiyle elde edildi. Trypan blue excluding li hücrelerin $\% 60$ oranndan daha fazlass. 100 mM NDMA. NDEA ve NPYR; $18 \mathrm{mM}$ NDDA, 10 $\mathrm{mM}$ NMOR, NPIP ve NMU: $3,2 \mathrm{mM}$ NFU ve $1 \mathrm{mM}$ 
Tablo 1. Karaciğ her hücrelerinin izolasyonundan elde edilen numunelerin hastalarına ait veriler.

Table 1. Details of patients from whom liver samples werc obtained for the isolation of hepatocytes

\begin{tabular}{|c|c|c|c|c|c|c|c|}
\hline & 1 & 2 & 3 & 4 & 5 & 6 & 7 \\
\hline Cinsiyet & Erkek & Kadın & Erkek & Erkek & Erkek & Kadın & Kitdın \\
\hline$Y$ atș $(y a l)$ & 58 & 47 & 71 & 54 & 70 & 39 & 80 \\
\hline Kriter iģiul tanı & $\begin{array}{l}\text { (Safra kanalı } \\
\text { karsinomu) }\end{array}$ & $\begin{array}{l}\text { Kavernöz } \\
\text { hemanjiom }\end{array}$ & $\begin{array}{l}\text { Kavernöz. } \\
\text { hemanjiom }\end{array}$ & $\begin{array}{l}\text { Karacizer } \\
\text { karsinomu }\end{array}$ & $\begin{array}{l}\text { Kistik kanal } \\
\text { stenozu }\end{array}$ & Hidatid kist & $\begin{array}{l}\text { Salfril kescsi } \\
\text { adenokarsinomu }\end{array}$ \\
\hline Bilirubin $(\mathrm{mg} / \mathrm{dl})$ & & 0.5 & 1.1 & 9.7 & 13.7 & 0.3 & 16.7 \\
\hline $\begin{array}{l}\text { ALP } \\
(U / L)\end{array}$ & & 78 & 10() & & 425 & & \\
\hline$A S T \cdot(I / L)$ & 31 & 24 & 36 & 551 & 63 & 32 & 156 \\
\hline$A L T(U / L)$ & 29 & 3130 & 41 & 1131 & 55 & 64 & 158 \\
\hline$y-G T(I J / L)$ & & 42 & & & 386 & 59 & \\
\hline CPK $(L ! / L)$ & & 22 & & 2026 & 34 & 73 & \\
\hline $\mathrm{LDH}(\mathrm{l} ; / \mathrm{L})$ & & 260 & & 574 & 163 & 207 & 256 \\
\hline \multirow[t]{2}{*}{ Canls hijcre (\%) } & 91 & 91 & 95 & 87 & 53 & 82 & 95 \\
\hline & 8 & 9 & 10 & 11 & 12 & 13 & 14 \\
\hline Cinsiyet & Erkck & Kadın & Kadın & Erkck & Erkek & Erkek & Erkck: \\
\hline$Y_{\text {atș }}\left(y_{1} !\right)$ & 68 & 66 & 67 & 66 & 52 & 65 & 75 \\
\hline Ameliyat için belirti & $\begin{array}{l}\text { Kolon } \\
\text { karsinomunun } \\
\text { karaciǧer } \\
\text { metastazları }\end{array}$ & $\begin{array}{l}\text { Kolon } \\
\text { korsinomunun } \\
\text { karacił̧er } \\
\text { metastazları }\end{array}$ & $\begin{array}{l}\text { Kolon } \\
\text { karsinomumun } \\
\text { karaciger } \\
\text { metastazları }\end{array}$ & $\begin{array}{l}\text { Karaciğer } \\
\text { karsinoınu }\end{array}$ & $\begin{array}{l}\text { Safra } \\
\text { kanalı } \\
\text { karsinomu }\end{array}$ & $\begin{array}{l}\text { Mide } \\
\text { adenokarsino- } \\
\text { munun karaciğcr } \\
\text { metastiatz. }\end{array}$ & $\begin{array}{l}\text { Kalritciger } \\
\text { adenomu }\end{array}$ \\
\hline Bilirubin ( $\mathrm{mg} / \mathrm{dl}$ ) & 0.3 & 0.4 & & 0.9 & 4.7 & 0.5 & 1.4 \\
\hline AL_P (Li/L) & 154 & 115 & & 152 & 181 & 103 & 136 \\
\hline $\operatorname{AST} `(U / L)$ & 40 & 37 & 15 & 142 & 93 & 51 & 73 \\
\hline $\operatorname{ALT}\left(L^{\prime} / L\right)$ & 30 & & 37 & 167 & 92 & 43 & 12 \\
\hline$y-G T(U / L)$ & 40 & 42 & & 589 & 234 & & 1.53 \\
\hline CPK (LI/L) & & . & & 79 & & & 34 \\
\hline $\mathrm{LDH}((\mathrm{L} / \mathrm{L})$ & & 209 & 374 & 197 & 165 & & 123 \\
\hline \multirow[t]{2}{*}{ Cilnh hiicre $(\%)$} & $7 !$ & 95 & 85 & 80 & 82 & 86 & 81 \\
\hline & 15 & 16 & 17 & 18 & 19 & 20 & \\
\hline Cunsiyer & Erkek & Kadın & Erkek & Erkek & Kadın & Erkck & \\
\hline$Y a ! s(y 1)$ & 74 & 70 & 35 & 57 & 66 & 56 & \\
\hline Ameliyst için belirti & $\begin{array}{l}\text { Karaciger } \\
\text { karsinomu }\end{array}$ & $\begin{array}{l}\text { Karaciğer } \\
\text { karsinomu } \\
\text { Noma }\end{array}$ & $\begin{array}{l}\text { Mide } \\
\text { karsinomunun } \\
\text { karaciğer } \\
\text { metastazı }\end{array}$ & Hidatid kist & Hidatid kist & $\begin{array}{l}\text { Yaygm safra kan } \\
\text { tıkanklığ ve } \\
\text { karaciger apsesi }\end{array}$ & inalı \\
\hline Bilirubin (mg/dl) & 0.9 & 0.6 & 0.6 & 0.7 & 0.5 & 0.9 & \\
\hline$A L P(U / L)$ & 94 & 136 & 104 & 69 & 421 & 289 & \\
\hline ASTA (U/L) & .27 & 28 & 36 & 21 & 31 & 48 & \\
\hline $\operatorname{ALT}(\mathrm{L} / \mathrm{L})$ & 96 & 22 & 47 & 79 & 32 & 159 & \\
\hline$y-G T(U / L)$ & 58 & 131 & & 32 & 178 & 353 & \\
\hline $\mathrm{CPK}(\mathrm{l} / \mathrm{L} / \mathrm{L})$ & 33 & 79 & 34 & 23 & 24 & 84 & \\
\hline I..DH $(\mathrm{L} / \mathrm{L} .)$. & 275 & 549 & 211 & 142 & 126 & 182 & \\
\hline Citnlı hilcre (\%) & 73 & 77 & 91 & 76 & 86 & 67 & \\
\hline
\end{tabular}

AL.P. alkalen fosfataz;:ASTa, aspartat aminotransferaz; AI.T, alanine aminotransferaz; y-GT, gamma glutamiltransferaz: CPK. kreattin fostokina\%: LDH, laktat dehidrogenaz.

NBU seviyesinde clde edildi. NDBA'da isc; düşük çözülebilirlik özelliğinden dolayı sitotoksik bir konsantrasyona ulaşamad. Her bir NOC için, sitotoksisite denemelerinde test edilen en yüksek doz, ilk denemede hücre biiyümesini \%30'dan daha aşağıya çckmek için, maksimum seviyedeydi. Benzer bir duyarlılığı elde etmek için, insan karaciğger hüicrelerindeki UDS ve DNA bö- lünnesini sağlayan NOC kapasitesi, ayn smif konsantrasyonlara maruz bırakıldıktan somra incelendi. Fakat, insan ve rat karaciğer hücreleri arasındaki veya aym türün farklı donörlerinden elde edilen hepatosit primer kültürü arasındaki sitotoksisitenin muhtemel farklılıklarmmm bulunması için canlı kalan hücre parçaları her bir denemede ölçüldü. NDMA 5 mM'lik konsantrasyon halinde pozitif 
kontrol olarak kullanıldı. Incelenen NOC'nin genotoksik etkilcrinin karşılaşırılması, NDEA'nın rat karaciğer hücreleri için daha toksik olmasına karşın. MMOR'nin sürekli hir şekilde insan karaciğer hüicrelerindeki hücre büyümesi ỉzerinde azalıcı bir etki sağladığını göstermektedir. Diğer tüm NOC'lerin, canlı kalan huicre parçaları açısından ikj tür arasında önemli bir fark oluşturmadığı ortilya çıkmışur. Sitotoksisite lest sonuçları, DNA elüsyon oramundaki bir artışn, örneğin; DNA bölünmesi gibi ve UDS'nin NDEA, NIPPA, NMOR. NPIP, NPYR. NML. NEU ve NBU tarafindan hem insan hen de rat karaciğer huicrelerinde uyarıldığında, bunların 0,1 'den 10 mM'ye kadar sımflandırılabilecek en küçiik efektif konsantrasyonlar olduğunu göstermiştir. Bunun aksine; DNA hasar ve tamirinin ya düşijk derecede ya da her iki türün, hepatosit primer kültürünün ve NOC'nin çözülebilirlik limitini gösteren $1 \mathrm{mM}$ 'lik NDBA'ya maruz bırakıldıklarunda hemen hemen hiç meveul olmadikları görüldü. Aklif NOC de DN $\Lambda$ bölünme miktarmnn doza bay̆glı olmasına karşın, zaman zaman daha yüksck konsantrasyonlarda toksisite uyarımyla DNA onarım sentezlerinin kısmi olarak engellenmesiyle karşılaşıldı.

Gencllikle aynı türün farklı donörlerinden alınan kiiltiirlere uygulanan NOC ile uyarılan DNA hasar ve tamir miktarında, hem insan hem de rat karaciğ miktarlarmda farklılıklar gözlendi. Tüm dencmelerde 5 mM'lik NDMA positif kontrol için kullamıldığ nndan (örneğin; 20 insan ve 20 ratun hepatosit primer kültürinde).

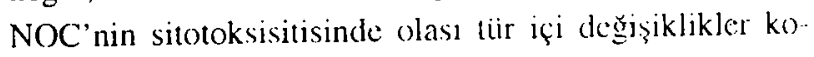
nusunda bilgi edinmenin en iyi yolu, bu yolla elde edilen verilerdir. $K_{4}-K_{c}$ olarak ölçuilen DNA böluimme mikıarı. insan karaciğerinde 5 katı iken ral hepatosit primer kuiltuiruinde 7 katıdır.

Bu büyüik tür içi değgşikliğe rağmen iki tür ara. sindaki DNA'nun hasar ve NDMA. NMOR. NPIP. NPYR ve NBU'mun UDS etkisi konusunda istatistik olarak önemli farklılıklar gö zlemlendi (Tablo 2).

\section{Tartışma ve Sonuç}

Hayvanlarda uygulanan kısa ve urun siireli deneylerden elde edilen sonuçlarm insana uyogulammass. kanser araşturmalarında önemli bir aşanadır (16.30). Esas problemlerden biri ksenobiyolik melabolizmadaki liirler arası farklılıkların varlığını ortaya koymaklır (13.18.25). Gerçekte kimyasalların kanserojenik etkisi kaımaşık bir süreç olmasına karşın, kanser süreci csnassndakı metabolik aktivasyonun ve daha sonraki IDNA hasarlarımm. tuimör oluşumunda önemli ilk adımlar olduğuna inanılır

Titblo 2. NOC'nin insan ve rat hepatositlerindeki DNA parçalanması ve programbanmamıs DNA sentezi potansiyeli.

Tible 2. Potency of NOC in inducing DNA fragmentation and unprogrammed DNA synthesis in humaun and rat hepattocyles.

\begin{tabular}{|c|c|c|c|c|}
\hline \multirow[b]{3}{*}{ Bilesikler } & \multicolumn{4}{|c|}{ Ortalama \pm standarl sapma } \\
\hline & \multicolumn{2}{|c|}{$\begin{array}{l}\text { D.VA-hasiar verme etkisi } \\
\qquad\left(\mathrm{X} \mathrm{mM}^{-1}\right)^{\mathrm{a}}\end{array}$} & \multicolumn{2}{|c|}{$\begin{array}{l}\text { UDS-oluşuturma ethisi } \\
\left(\mathrm{X} \mathrm{m}^{-1} \mathrm{M}^{\mathrm{h}}\right.\end{array}$} \\
\hline & Insan & Rat & Insan & Rat \\
\hline NDMA & $10.012 \pm 3.76$ & $18.37 \pm 4.24 c$ & $4.115 \pm 1.55$ & $4.48 \pm 2.57$ \\
\hline NDEA & $2.21 \pm 0.58$ & $3.112 \pm 1.26$ & $1.89 \pm 0.61$ & $1.69 \pm 0.80$ \\
\hline$\therefore D P A$ & $5.19 \pm 3.33$ & $7.48 \pm 3.43$ & $4.11 \pm 2.33$ & $6.45 \pm 3.75$ \\
\hline VMOR & $14.011 \pm 1.78$ & $14.95 \pm 6.26$ & $10.97 \pm 6.26$ & $3.53 \pm 1.83 \mathrm{~d}$ \\
\hline NPIP & $6.27 \pm 1.29$ & $2.43 \pm 1.74 c$ & $2.14 \pm 2.63$ & $10.17 \pm 4.52 \mathrm{~d}$ \\
\hline NPYR & $1.33 \pm 0.43$ & $3.19 \pm 1.96 \mathrm{e}$ & $4.60 \pm 3.83$ & $1.75 \times 1.12 \mathrm{e}$ \\
\hline NML: & $27.23 \pm 6.41$ & $31.88 \pm 12.09$ & $20.54 \pm 9.60$ & $30.28 \pm 15.14$ \\
\hline NEU & $16.88 \pm 9.36$ & $11.34 \pm 4.03$ & $7.58 \times 5.53$ & $7.84 \pm 3.90$ \\
\hline NBC & $71.78 \pm 26.76$ & $31.03 \pm 14.000 \mathrm{c}$ & $54.26 \pm 19.52$ & $19.90 \pm 10.250$ \\
\hline
\end{tabular}

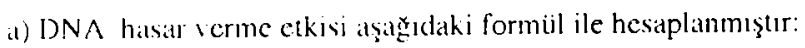

$$
\frac{(\mathrm{KI}-\mathrm{Kc})}{\text { Yoğunluk (mM) }} \times 1()(k)
$$

Bu formüilde "(Kt-Kc)" kontrol ijzcrinde filtreden geçme oranıdır. Değgerler 3 değişik yoğunluk scviyesinde test edilen DNA-hassar verme kuvvellerinin averajidir.

b) UDS oluşuturma ctkisi aşağ̊daki forıülui kullanarak hesaplanmışır:

$$
\text { (NGt-NGc) }
$$

Yoğunluk (mM)

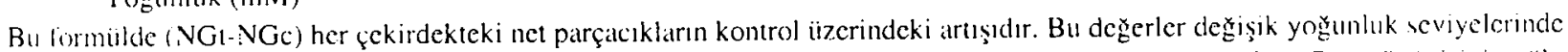

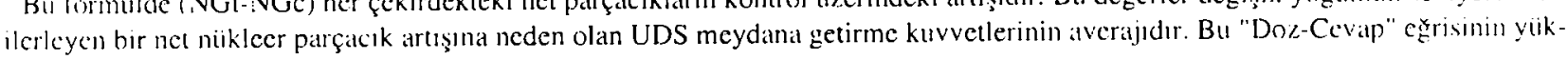
sclen böluimuidur.

c) $p<() .()())-t-$ testi (Student t testi)

d) p<0.()1-t-testi (Sudent t testi)

c) $p<(1 .(1) 5-t-t e s t i \quad$ Student testi) 
(11.22). Harris (10) tarafindan son zamanlarda incelendiği gibi, laboratuvar hayvanlanndan ve insan donörlerden alman hücrelerdeki sitotoksisitc ve kimyasal metabolizma üzerinde yapilan araştırmalar in vitro olarak da karşılaştırma yapmak için eşsiz fırsatlar sunar (13,2628). Özellikle, izolc edilmiş insan karaciğer hücrelerindeki, kinyasal kanserojenlerin metabolik harekelleri ve hareketsizliklerindeki tür içi ve türler arası değışikliklerin değcrlendirilmesi büyük değere sahiptir. NOC, bitçok çeşit hayvan türünde tümör yapan kuvvetli bir kanserojen grubunu tensil ettiği için, insanlardaki kanser riskinin tayininde ek bilgi clde etmek adına, insan ve rat karaciğer hücrelerinin primer kültürlerindeki uyancs DNA hasar ve tamir sentezlerinin 10 adel NOC'sinin kapasitesini karşılaştımanın faydalı olacağı düşünülddü. Bu sitotoksisitenin uç noktalarının seçimi metabolik olarak yeler miktardaki primer karaciğer hücre kül liirlerindeki UDS'nin ve DNA bölïnmesinin birçok sınıf kanserojen madde için potansiycl olan kanserojen göslergelerinin doğruluğunu gösteren birçok deneysel kanıtla gözlendi (31.36-38). Elde edilen sonuçlar, incelenen 10 NOC'nin, (NDMA, NDEA, NDPA, MMOR, NPIP, NPYR, NMU, NEU, NBU, NDBA) karaciger huicrelerinde DNA tamir sentezleri oluşturduğunu göslemişlis. DNA da, az çözuilebilirliğgi nedeniyle test edilehilen naksimum konsantrasyondaki ( $1 \mathrm{mM}$ ) NDBA, her iki türün hepatosit primer kuiltürüde zaman zaman az. aktivite göstermiş. bazen de hiç aktivite göstermemiştir. NOC nin incelenen tesı sonuçlarının bir kısmı aşağıda belirtilen leș sonuçlarıyla uyumludur. Insan karaciğer hücrelerinin primer kiilturleri NDMA'ya $(5-7,3.3)$ ve NDEA (33.34) ya maruz brakıldıktan sonra UDS'nin indüksiyont fark edildi ve aym NOC'nin ikinci kez kültürü yapılmış insaan fibroblastlarının mutasyonuna sebep olan ürülere tepki vermesi için insan karaciğer hücreleriyle harekete geçirildiği ortaya çıkmıştır $(13,34)$. Insan karaciğerindsn elde edilen ömeklerin. NDMA, NDPA, NPIP. NPYR ve N-nitrosomethylcthylamine $(27,28)$ için yaptlan Ancs testinde etkin bir mutagenik aktivator olduğgu görüilmüiştür. Nükleik asit metilasyon ve in vitro'daki insan karaciğer dilimleriyle NDM $\Lambda$ 'nın metabolizmasi 1970'te Montesano ve Magee (23) tarafindan taril edildi ve yeni metillenmiş pürinlerin NDMA zehirlenmesinden sonra insan karaciğer DNA'sinda mevcut olduğ furkedilmiştir (12). Insan ve rat karaciğer hücrelcrinde UIDS nin meydana çımısı ve DNA'nın hasar görmesind: rol oynayan 9 aktif NOC'nin ortalama etkisi. Tablo 2'do gösterilmiştir. Iki tür arasında istatik olarak önemli bir fark olduğu NDMA, NMOR, NPIP, NPYR ve NBU ile oltaya konulmuştur. DNA'nın hasar verici oranı
NPIP ve NBU insan karaciğer hücreleri karrş1sında dahal aktif olmasına karşın. NDMA ve NPYR'nin rat karaciğ hiicreleri karşısında daha aktif olduğ göruilmuiş̧tir. UDS. NMOR. NPYR ve NBU'yu uyarma oram insianda daha çok iken, NPIP ratlarda daha kuvvetlidir. NPIP'nin. insan karaciğer hücresinin DNA'sına daha hiiyitik ölçuide hasar vermesi ve bunun aksine ratlarda DNA onarmmm teşvik etmede daha aktif olmasi ve tam tersinin de NPYR de oluştuğu dikkate deg̣erdir. UDS miktarı sadece DNA le\%. yonlarının sıklığına değil aynı zamanda iki lüı için farklı olabilecek olan DNA onarım sentezlerini içeren enzim sistemlerinin aktivitelerine de bağl olduğu için yukarı daki farklılıklar şaşırıcı değildir. Her bi.r N-nitroso bileşiğinin genotoksik aktivitesini değerlendimek için kullanılan iki tïrün az sayslaki donörleri nedeniyle. go\% lemlenen türler arasındaki DN $\Lambda$ nn hasal verici ve UDS'nin uyarıcı gücuindeki farklılıklar, istalistik açıdan önemli olsa bile, tedbirli bir şekilde yorumlanmalıdır. Bazı NOC'ler için insan ve rat karaciğer hïcreleri arasmda miktarsal farklılıklarm bunların hareketlerini ve detoksikasyonlarım içeren metabolik sürę̧lerinin randımanyyla oluşabilme olasılığı bir ornektir. Bu yöniiyle hulgularımızın. NOC'nin duyarlılı̆̆ı açısından tür içi larklılıkların gerçektc iki tür arası farklılıktiın daha biiy iik olal. bilmesi olasılığını göstermesi açısından önemlidir. Yatten. iki türün birçok donörü üzerinde (20 insan-20) rat) yapılan tek NOC testi olan NDMA'dan elde edilen somuçlar. bu bileşiğin ortalama DN $\Lambda$ hasar gücui, insanda rattan sadece 1,5 kat daha büyüik olduğgnu göstermiş̧ir. Buna karşın. ayn parametre. sözu edilen ilk turün farklı donörleri aliasunda $2,5 \mathrm{~kat}$, ikinci türün farkl donörleri arasında ise 6 kat gibi bir değgşkenlik gösterdi. Farklı insan do. nörlerinden elde edilen hepatosit primer kiiltuirtindeki NOC ile uyarılan UDS ve DNA bölünme mikıarlarında ölçülebilir variyasyonlar tespit edildi. Bu varyasyonlar, DNA onarım sentezlerinin etkinliğindeki farklılıklardan olduğu kadar patolojik şartlardan, ilaçlardan. geda mad delerinden, cinsiyetten. yaş̧an da etkilendiğ̣j bilinen. kalraciğer detoksifikasyon enzimlerinin harekelerindeki farklılıkları da yansılahilir.

Fakat, bu çalışmadaki veriler, donörlerin yaş ve cinsiyctlerinin kalıtsal bir etkisi olduğunu göstermedi. Ayrıca, karaciğer fonksiyonlarm değerlendirmek için öl. çïlen biyokimyasal parametrelerdeki deg̣işiklikler ile UDS ve DNA hasar miktarları arasinda da herhangi bir ilişki saptanamad. Sadece. birçok deney sayesinde clde toplanan veriler, bu variyasyonlarm nedenleri konusunda ayrıntılı analizler yapılmasını sağladı.

Sonuç olarak, rat karaciğger hücrelerinin NOC'nin genotoksik etkisini anlamak için çalışmanm uyg̣ın bir model olduğ gunu gösterdi. 


\section{Kaynaklar}

1. Bartsch H, Montesano R (1984): Relevance of nitmosamines to human cancer. Carcinogenesis (Lond). $\mathbf{5}$. $1381-1393$

2. Bogovski P, Bogovski S (1981): Animal species in which N-nitroso compounds induce cancer. Int J Cancer, 27, 471474.

3. Bradley MO, Dysart G, Fitzsimmons $K$, Harbach $P$, Lewin J, Wolf G (1980): Measurements by filter elution of DNA single and double strand breaks in rat hepatocytes: effects of nitrosamines and Firradiation. Cancer Res. 42, 2592-2597

4. Brambilla (;, Cavanna M, Parodi S, Sciaba L, Pino A, Robbiano L (1978): DNA danage in liver, colon, stomach. lung and kidney of $B A L B / C$ mice treated with 1.2 dimethylhydrazine. Int J Cancer, 22, 174-180.

5. Butterworth BE, Bermudez E, Smith-Oliver T, Earle $\mathbf{L}$, Cattley R, Martin J, Popp JA, Strom S, Jirtle R, Michalopoulos $\mathbf{G}$ (1984): Lack of genotoxic activity of di(2ethythexyl)phthalate (DEHP) in rat and human hepatocytes Carcinogenesis (Lond), 5. 1329-1335.

6. Butterworth BE, Earle LI, Strom SC, Jirtle RL, Michalopoulos (; (1983): Measurement of chemically induced DNA repair in human hepatocytes. Proc Am Assoc Cancer Res. 24. 69.

7. Butterworth BE, Larle $L$, Strom S, Jirtle R, Michalopoulos ( $\mathbf{B}$ (1983): Induction of DNA repair in human and rut hepatocyles by l,6-dinitropyrene. Mutat Res, 122. 73-80).

8. Cole KE, Hsu IC, Trump BF (1986): Comparative ultrastructural effects of aflatoxin $B /$ on inouse, rat, and human hepatocyles in primary culture. Cancer Res, 46. 1290)-1296.

9. Druckrey H, Preussmann R, Ivankovic S, Schmahl D (1967): Organomope carcinogene Wirkungen bei 65 verschiedenen N-Nitroso-Verbindungen an BD-Ratten. Z Krebsforsch. 69. 1(13-201).

10. Harris CC (1987): Human tissues and cells in carcinogenesis research. Cancer Res, 47, 1-10.

11. Heidelberger C (1975): Chemical carcinogenesis. Annu Rev Biochem, 44, 79-121.

12." Herron DC, Shank RC (1980): Methylated purines in human liver DNA after probable dimethylnitrosamine poisoning. Cancer Res, 40. 3116-3117.

13. Hsu IC, Harris CC, Lipsky MM, Snydw S, Trump BF (1987): Cell and species differences in metabolic activation of chemical carcinogens. Mutal Res, 177, 1-7.

14. International Agency for Research on Cancer (1978): IARC Monographs on the Evaluation of the Carcinogenic Risk of Chemicals to Humans. Some N-Nitroso Compenunds. Vol. 17. Lyon. France: IARC.

15. Jones CA, Huberman E (198(1): A sensitive hepatocytemediated assay for the metabolism of nitrosamines to mula'sens for mammalian cells. Cancer Res, 40, 406-411.

16. Kito K, Kihana T, Sugita A, Murao S, Akehi S, Sato M, Tachibana M, Kimura S, Ueda N (1996): Incidence of p53 and Ha-rass gene mutations in chesnically induced rat mammary carcinomas. Mol Carcinog. 17. 78-83.

17. Kohn KW, Erickson LC, Ewig RAG, liriedman CA (1976): Fractionation of DNA from mammalian cells by al. kaline elution. Biochemistry. 15, 4629-4637.

18. Langebach R, Nesnow S, Rice JM (1983): Orgsin and Species Specificity in Chemical Carcinogenesis. Plonum Press. New York.

19. Lu SH, Ohshima H, Fu HM, Tian Y, Li FM, Blettner M, Wahrendorf J, Bartseh H (1986): Urinary exiretion of $N$-nitrosamino acids and nitrate by inhabitants of highand low-risk areas for esophageal cancer in Nerthern China: endogenous formation of nitrosoproline and its inhibition by vitumin C. Cancer Res. 46. 1485-1491.

20. Magee PN, Barnes JM (1967): Carcinogentic nitresso compounds. Adv Cancer Res. 10. 163-24

21. Martelli A, Robbiano L, Ghia M, Giuliano I, Angelini G, Brambilla G (1986): A stuct of the potential senotoxicity of cimetidine using human hepatecyte primatry cultures: discrepancy from results obtained in ith hepatocytes. Cancer Lett, 30. $11-16$

22. Miller EC (1978): Some current perspectives on chemical carcinogenesis in humans and experimental animals. Cancer Res, 38. 1479-1496.

23. Montesano R, Magee PN (197()): Metubolism of dimethylnitrosamine by human liver slices in vitro. Vature (Lond), 228. 173-174.

24. Moore C.J, Gould MN (1984): Metabolism of benzol (a)pyrene hy cultured human hepatocyles from mulhiple donors. Carcinogenesis (Lond). 5. 1577-1582

25. Muller D, Nelles J, Deparade E, Arni P (1980): The acfivity of Sy-liver fractions from seven species in the Salmonella/mammalian-microsome mutageneicity. test. Mutat Res, 70, 279-30).

26. Neis JM, Roelofs HMJ, van Gemert P.JL, Henderson P'T (1986): Mutagenicity towards Salmonella Nyphimuram of some known senotoxic agents. activated by isolitied hepatocytes of monkey (Macaca fascicularis.) Comparison with isolated human hepatocytes. Mulat Res. 164. 139-143.

27. Neis JM, Yap.SH, van Gemert PJIL, Roelof's HMJ, Bos RP, Henderson I'T (1986): Assay of mulcigene by hepatocytes and liver $9000 \mathrm{xg}$ supernatam from human origin in the Salmonella typhimurium mutagenicity assat: Comparison with rat liver preparations. Mutat Res. 164. $41-56$

28. Phillipson CE, Ioannides C (1984): A comparamile sudty of the bioactivation of nitrosamines of mukagens bi watous animal species including man. Carcinogencsis (loond). 5. $1091-1094$

29. Preston-Martin S, Yu MC, Benton B, Henderson BE (1982): Nitroso compounds and childhosd brain tumors: a case-control study. Cancer Res, 42. 524(1)-5245.

30. Qin X, Zarkovic M, Nakatsuru Y, Arai M, Oda H, Ishikawa $\mathrm{T}$ (1994): DNA adduct formation and assessmemt of aberran crypt foct in wive in the rat colon mucosa after treatment with $N$-methyl-N-nimosourea. Carcinogenesis. 15, 851-855. 
31. Sina JF, Bean CL, Dysart (GR, Taylor VI, Bradley MO (1983): Evaluation of the alkaline elution/rat hepatocyte assa: as a predictor of carcinogenic/mutagenic potential Mutat Res, 113. 357-391.

32. Singer GM, Chuan J, Roman J, Min-Hsin L, I,ijinsky W (1986): Nitrosamines and nitrosamine precursors in foods from Linxian, China. "high incidence area for esophageal cancer. Carcinogenesis (Lond), 7. 733-736.

33. Strom SC, Jirtle RL, Jones RS, Novicki DL, Rosenherg MR, Novotny A, Irons G, McIain JR, Michalopoulos G (198.): Isolation. cullure, and transplantation of human hepanocytes. J Natl Cancer Inst. 68. 771-778.

34. Strorn SC, Novicki DL, Novotny A, Jirtle RL, Michalopoulos G (1983): Human hepatocyte-mediated mulagenesis and DNA repair activin: Carcinogenesis (Lond), 4. 663-686.

35. Williams (GM (1976): Primary and long-term culure of adult rat liver epithelial cells. Methods Cell Biol, 14, 357 364.
36. Williams GM (1977): The detection of chemical carcinogens by unscheduled DNA sinthesis in rat liver primary cell cultures. Cancer Res. 37. 1845-1851.

37. Williams GM, Laspia MF (1979): The detection of $\mathrm{va}$ rious nitrosamines in the hepatocyte primary culturefDNA repair test. Cancer Lett. 6, 199-2(1)6

38. Williams GM, Laspia MF, Dunkel VC (1982): Reliabiliny of the hepatocyte primary culture/DNA repair lest in lestinl' of coded carcinogens and noncarcinogens. Mutall Res. 97. 359-370.

Gelis tarihi : 26.6.2001/Kabul tarihi : 24.10.2001

Yazışma adresi:

Doç:Dr.Taner Pamukçu

Kırıkale Universitesi,

Veteriner Fakültesi

71450 Kampüs

Yahsihan Kerikkale 